\title{
Effects of irrigation and nitrogen management on hybrid maize seed production in north-west China
}

\author{
Hui RAN ${ }^{1}$, Shaozhong KANG ${ }^{1}$, Fusheng LI $^{2}$, Ling TONG ${ }^{1}$, Taisheng DU (凶) ${ }^{1}$ \\ 1 Center for Agricultural Water Research in China, China Agricultural University, Beijing 100083, China \\ 2 College of Agriculture, Guangxi University, Nanning 530005, China
}

\begin{abstract}
Scientific irrigation and nitrogen management is important for agricultural production in arid areas. To quantify the effect of water and nitrogen management on yield components, biomass partitioning and harvest index $(H I)$ of maize for seed production with plastic filmmulching, field experiments including different irrigation and $\mathrm{N}$ treatments were conducted in arid north-west China in 2013 and 2014. The results indicated that kernel number per plant $(K N)$ was significantly affected by irrigation and $\mathrm{N}$ treatments. However, 100-kernel weight was relatively stable. Reducing irrigation quantity significantly increased stem partitioning index $\left(P I_{\text {stem }}\right)$ and leaf partitioning index $\left(P I_{\text {leaf }}\right)$, and decreased ear partitioning index $\left(P I_{\text {ear }}\right)$ at harvest, but lowering $\mathrm{N}$ rate (from 500 to $100 \mathrm{~kg} \mathrm{~N} \cdot \mathrm{hm}^{-2}$ ) did not significantly reduce $P I_{\text {stem }}, P I_{\text {leaf }}$, and $P I_{\text {ear }}$ at harvest. $H I$ was significantly reduced by reducing irrigation quantity, but not by reducing $\mathrm{N}$ rate. Linear relationships were found between $K N, P I_{\text {stem }}, P I_{\text {leaf }}, P I_{\text {ear }}$ at harvest and $H I$ and evapotranspiration (ET).
\end{abstract}

Keywords yield components, biomass partitioning, harvest index, irrigation, nitrogen, maize for seed production

\section{Introduction}

Irrigation and nitrogen management is the most critical element of agricultural production in arid areas ${ }^{[1-5]}$. Scientific and rational management of irrigation and $\mathrm{N}$ is important for the high yield and high efficiency of agriculture in arid areas. The economic yield of crops is closely related to the changes in yield components, biomass partitioning and harvest index $(H I)$. Quantifying

Received December 16, 2015; accepted March 3, 2016

Correspondence: dutaisheng@cau.edu.cn the response of yield components, biomass partitioning and $H I$ to different water and $\mathrm{N}$ treatments cannot only provide available parameters for crop yield modeling, but also provide the scientific basis for crop irrigation and $\mathrm{N}$ management.

Kernel number per plant $(K N)$ and 100-kernel weight $(K W)$ are two major components of yield. There are many reports about the effects of water and $\mathrm{N}$ on yield components of maize ${ }^{[6-10]}$. However, the effects of water and $\mathrm{N}$ on yield components vary with its growing environment, thus studying crop response to water and $\mathrm{N}$ for specific climate, soil conditions, and agronomic practice is still needed. In addition, previous studies have focused on maize yield, but there have been relatively few reports on effects of irrigation and $\mathrm{N}$ management on yield components of maize for seed production.

Biomass partitioning is closely related to crop cultivar and environmental factors ${ }^{[11-14]}$. However, there are many studies on biomass partitioning, which mostly concentrated on the root-shoot ratio. It was found that soil water deficit significantly reduces shoot dry mass in maize but only reduces root dry mass slightly, thus it increases rootshoot ratio ${ }^{[15]}$. Other studies indicated that under drought conditions, crop growth rate and biomass production are reduced to decrease water consumption, and more biomass is transferred to the roots to maintain a higher root-shoot ratio $^{[16-25]}$. It was also showed that the proportion of root dry mass does not increase under drought conditions ${ }^{[26]}$. Plant biomass partitioning has mostly been analyzed using aboveground and belowground parts, but aboveground measurements of biomass partitioning into different organs (stem, leaf and ear) are also needed ${ }^{[13]}$. In addition, there are relatively few examples of continuous measurements of changes of biomass partitioning over the whole growth period.

$H I$, the ratio of economic yield and biomass, reflects the capacity of crop photosynthate to be converted to economic product, and is an important index in evaluating 
the yield of crop cultivars and cultivation practices. It was found that water stress significantly decreases $H I$ in maize, even reducing it to zero ${ }^{[27]}$. Other studies likewise indicated that water stress reduces $\mathrm{HI}^{[28-30]}$. However, proper reduction of irrigation quantity can increase $H I$ and $\mathrm{N}$ rate had no effect on $\mathrm{HI}^{[9,15,31-34]}$, although $\mathrm{N}$ deficit decreases $H I^{[35]}$. Despite the many studies on $H I$, the response of $H I$ to different irrigation and $\mathrm{N}$ treatments is still poorly understood.

Thus a two-year field experiment on yield components, biomass partitioning and $H I$ in maize for seed production with plastic film-mulching under different irrigation and $\mathrm{N}$ treatments was conducted in arid north-west China. The objectives of this study were to (1) quantify the response of yield components, biomass partitioning and $H I$ in maize for seed production under different irrigation and $\mathrm{N}$ treatments, and (2) develop relationships between yield components, biomass partitioning and $H I$ and evapotranspiration $(E T)$ under different $\mathrm{N}$ rates. The latter was to provide parameters for crop yield modeling and a scientific basis for irrigation and $\mathrm{N}$ management of maize under these growing conditions.

\section{Materials and methods}

\subsection{Experimental site and description}

Field experiments were conducted at Shiyanghe Experimental Station of China Agricultural University, located near Wuwei, in Gansu Province, China $\left(37^{\circ} 52^{\prime} \mathrm{N}\right.$, $102^{\circ} 50^{\prime}$ E, $1581 \mathrm{~m}$ ) during April to September, 2013 and 2014. The experimental site is in an inland arid desert climate zone where light and heat resources are abundant, with mean annual duration of sunshine of over $3000 \mathrm{~h}$, mean frost free days of over 150 days, mean annual temperature of $8^{\circ} \mathrm{C}$ and annual accumulated temperature $\left(>0^{\circ} \mathrm{C}\right)$ of $3550^{\circ} \mathrm{C}$. The site had limited water resources, with annual precipitation of $164 \mathrm{~mm}$, mean annual pan evaporation approximate of $2000 \mathrm{~mm}$, and the groundwater table was below $25 \mathrm{~m}^{[36]}$. The soil texture was a light sandy loam, with mean soil dry bulk density of $1.40 \mathrm{~g} \cdot \mathrm{cm}^{-3}$, mean field capacity $(F C) 0.30 \mathrm{~cm}^{3} \cdot \mathrm{cm}^{-3}$ and mean permanent wilting point $0.10 \mathrm{~cm}^{3} \cdot \mathrm{cm}^{-3}$ for the 0 $100 \mathrm{~cm}$ layers.

\subsection{Experimental methods}

In 2013, three irrigation treatments, namely 65-70 (W1),
55-60 (W2) and 45\%-50\% FC (W3), and three nitrogen (N) treatments, namely 500 (local $\mathrm{N}$ rate, N500), 400 (N400) and $300 \mathrm{~kg} \mathrm{~N} \cdot \mathrm{hm}^{-2}$ (N300), totaling 9 treatments were applied. Maize (Zea mays cv. Funong340) was sown on 20 April and harvested on 11 September. In 2014, the experimental design was adjusted in response to the results in 2013. Three irrigation treatments, namely 65-70 (W1), 55-60 (W2) and 45\%-50\% FC (W3), and three N treatments, namely 500 (N500), $300(\mathrm{~N} 300)$ and $100 \mathrm{~kg}$ $\mathrm{N} \cdot \mathrm{hm}^{-2}(\mathrm{~N} 100)$, totaling 9 treatments were applied. Maize was sown on 15 April and harvested on 20 September. The irrigation method was border irrigation. Irrigation treatment was controlled according to the lower limit of $F C$. In each irrigation treatment, water was applied to $F C$ when soil water content reached the controlled lower limit. Two experiments were conducted in a randomized complete block design with three replicates. $\mathrm{N}$ fertilizer was applied as urea $(46 \% \mathrm{~N})$. Phosphorus $\left(\mathrm{P}_{2} \mathrm{O}_{5}\right)$ and potassium $\left(\mathrm{K}_{2} \mathrm{O}\right)$ fertilizers were applied at 240 and $50 \mathrm{~kg} \cdot \mathrm{hm}^{-2}$, respectively, in both years. Fertilizer application time and method were similar for all treatments. Maize was planted with one line of male plants and five lines of female plants with plastic film-mulching. Plant spacing was $0.25 \mathrm{~m}$, row spacing was $0.4 \mathrm{~m}$, and planting density was 100000 plants per hectare. Female plants were manually emasculated before flowering. Except for irrigation and $\mathrm{N}$ fertilizer, other farming measures were similar for each treatment.

Plot area was $86.8(12.4 \times 7.0) \mathrm{m}^{2}$ and the plots were separated by ridges $(0.3 \mathrm{~m}$ wide and $0.5 \mathrm{~m}$ high) with $1 \mathrm{~m}$ wide strips around the inside of each plot as the protected area. Each plot was divided into three sub-plots, and one sub-plot was used for biomass destructive sampling and the other two sub-plots for the measurements of soil water content, and yield components.

\subsection{Measurements}

\subsubsection{Meteorological data}

The meteorological data including precipitation $(P)$, solar radiation $(R s)$, air temperature $(T)$, wind speed at $2 \mathrm{~m}$ aboveground $\left(u_{2}\right)$ and relative humidity $(R H)$ during the whole growth period, were continuously measured by a standard automatic weather station (Hobo, Onset Computer Corporation, Cape Cod, Massachusetts, USA) about $100 \mathrm{~m}$ away from the experimental field (Table 1). The data were taken at $5 \mathrm{~s}$ interval, and $15 \mathrm{~min}$ averages were calculated and recorded using a data logger. The reference

Table 1 Meteorological variables over the whole growth period of maize for seed production with film-mulching in $2013 / 2014$

\begin{tabular}{lcccc}
\hline Year & Average $R s /\left(\mathrm{W} \cdot \mathrm{m}^{-2}\right)$ & Average $T /{ }^{\circ} \mathrm{C}$ & Average $R H / \%$ & Total $P / \mathrm{mm}$ \\
\hline 2013 & 209.2 & 18.8 & 52.8 & 68.2 \\
2014 & 216.6 & 17.4 & 58.1 & 526.3 \\
\hline
\end{tabular}

Note: $R s$, solar radiation; $T$, air temperature; $R H$, relative humidity; $P$, precipitation; $E T_{0}$, reference evapotranspiration. 
crop evapotranspiration $\left(E T_{0}\right)$ was calculated using the equation of FAO 56 Penman-Monteith ${ }^{[37]}$.

\subsubsection{Soil moisture content}

In each plot, two TRIME tubes were installed to allow measurement of moisture content using a time domain reflectometer (TRIME-PICO-IPH, IMKO, Ettlingen, Germany). Measurements were made at the depths of 20, 40, 60,80 and $100 \mathrm{~cm}$ every 7 days, and the mean soil water content over the $0-100 \mathrm{~cm}$ depths was used to determine irrigation time. The reflectometer measurements were calibrated gravimetrically. Irrigation quantity was determined by the difference of actual soil water content and field capacity (Table 2).

Table 2 Controlled lower limit of field capacity over the whole growth period applied to maize for seed production with film-mulching in 2013 and 2014

\begin{tabular}{lcccc}
\hline Year & Treatment & $\begin{array}{c}\text { Controlled lower limit } \\
/(\% F C)\end{array}$ & $I / \mathrm{mm}$ & $\begin{array}{c}\text { Irrigation } \\
\text { number }\end{array}$ \\
\hline 2013 & W1N500 & $65-70$ & 339 & 4 \\
& W2N500 & $55-60$ & 238 & 3 \\
& W3N500 & $45-50$ & 132 & 1 \\
W1N400 & $65-70$ & 280 & 4 \\
& W2N400 & $55-60$ & 230 & 3 \\
W3N400 & $45-50$ & 157 & 1 \\
W1N300 & $65-70$ & 288 & 4 \\
W2N300 & $55-60$ & 243 & 3 \\
W3N300 & $45-50$ & 133 & 1 \\
W1N500 & $65-70$ & 274 & 4 \\
W2N500 & $55-60$ & 179 & 2 \\
W3N500 & $45-50$ & 115 & 1 \\
W1N300 & $65-70$ & 265 & 4 \\
W2N300 & $55-60$ & 227 & 2 \\
W3N300 & $45-50$ & 117 & 1 \\
W1N100 & $65-70$ & 333 & 4 \\
W2N100 & $55-60$ & 242 & 2 \\
W3N100 & $45-50$ & 115 & 1 \\
\hline
\end{tabular}

Note: $\mathrm{W}$, irrigation quantity; $\mathrm{N}$, nitrogen rate; $F C$, field capacity; $I$, irrigation.

\subsubsection{Actual crop evapotranspiration}

$E T$ for each treatment was calculated as:

$$
E T=\Delta W+I+P+S_{g}-D-R_{f}
$$

where $E T$ is crop evapotranspiration, $\Delta W$ the change in soil water storage between two soil moisture content measurements, $I$ irrigation water applied during the growth period,
$P$ precipitation, $S_{g}$ the capillary rise from the lower soil layer to the crop root zone, $D$ the amount of drainage water, and $R_{f}$ the amount of runoff. $S_{g}$ was ignored due to the deeper water table in this area. $R_{f}$ was zero due to the basin irrigation system. $D$ was ignored because the upper limit of irrigation was field capacity.

\subsubsection{Yield components}

At the end of each season, 20 female plants were randomly chosen from each plot and harvested for $K N$ and $K W$. Grains were first dried at $105^{\circ} \mathrm{C}$ for $30 \mathrm{~min}$, and then dried at $60-70^{\circ} \mathrm{C}$ to constant mass. One hundred grains were randomly chosen from each plot and weighed to give $K W$. $K N$ was obtained from grain yield per plant divided by the individual seed weight calculated from $K W$.

\subsubsection{Biomass and its partitioning index}

Three plants from each plot were cut at ground level every 10 to 20 days to determine aboveground biomass production, and biomass partitioning into stem (including stems and sheaths), leaf (including green leaves and dead leaves) and ear (including peel, core axis and grain). Each part was separately dried at $105^{\circ} \mathrm{C}$ for $30 \mathrm{~min}$, and then dried at $60-70^{\circ} \mathrm{C}$ to constant mass. Stem partitioning index $\left(P I_{\text {stem }}\right)$, leaf partitioning index $\left(P I_{\text {leaf }}\right)$ and ear partitioning index $\left(P I_{\text {ear }}\right)$ were calculated as follows:

$$
\begin{gathered}
P I_{\text {stem }}=\frac{S_{\text {mass }}}{S_{\text {mass }}+L_{\text {mass }}+E_{\text {mass }}} \\
P I_{\text {leaf }}=\frac{L_{\text {mass }}}{S_{\text {mass }}+L_{\text {mass }}+E_{\text {mass }}} \\
P I_{\text {ear }}=\frac{E_{\text {mass }}}{S_{\text {mass }}+L_{\text {mass }}+E_{\text {mass }}}
\end{gathered}
$$

where $S_{\text {mass }}$ is stem dry mass (g), $L_{\text {mass }}$ leaf dry mass (g), and $E_{\text {mass }}$ ear dry mass $(\mathrm{g})$.

\subsubsection{Harvest index}

At the end of each season, 20 female plants were randomly chosen from each plot and harvested for grain yield. Grains were first dried at $105^{\circ} \mathrm{C}$ for $30 \mathrm{~min}$, and then dried at 60 $70^{\circ} \mathrm{C}$ to constant mass. The final grain yield was expressed on the basis of water content of $13 \%$. HI (\%) was calculated as:

$$
H I=\frac{Y}{B} \times 100
$$

where $Y$ is yield $\left(\mathrm{t} \cdot \mathrm{hm}^{-2}\right)$ and $B$ final aboveground biomass $\left(\mathrm{t} \cdot \mathrm{hm}^{-2}\right)$. 


\subsection{Statistical analysis}

Analysis of variance (ANOVA) was performed using the general linear model (univariate procedure) from SPSS 21.0 software (IBM SPSS Statistics, USA). ANOVAs were done with irrigation and $\mathrm{N}$ fertilizer as the main effects and including their interactions. All the treatment means were compared for any significant differences using the Duncan's multiple range tests at significance level of $P \leqslant 0.05$. Regression analyses were performed using Microsoft Excel. There was more rainfall in 2014 than 2013, and experimental design was slightly different for 2 years, resulting in a differential seasonal response. Therefore, the effects of different irrigation and $\mathrm{N}$ treatments on maize for seed for 2013 and 2014 were analyzed separately.

\section{Results and discussion}

3.1 Kernel number per plant and 100-kernel weight

$K N$ and $K W$ are two major components of yield. Irrigation quantity had a significant effect on $K N(P<0.001)$ in both years (Table 3). Compared with W1 in 2013, W2 and W3 reduced the $K N$ by $35.4 \%$ and $62.1 \%$, respectively. Likewise, compared with W1 in 2014, W2 and W3 reduced the $K N$ by $22.9 \%$ and $52.9 \%$, respectively. The effect of $\mathrm{N}$ rate on $K N$ was significant $(P<0.05)$ in 2014, but not significant in 2013 (Table 3). Compared with N500 in 2014, N300 and N100 reduced $K N$ by $4.4 \%$ and $15.5 \%$, respectively. Therefore, lowering irrigation quantity significantly reduced $K N$, while reducing $\mathrm{N}$ rate had less effect on $K N$, which was similar to the effect on yield. In addition, the interaction of irrigation and $\mathrm{N}$ had no significant effect on $K N$ in both years (Table 3 ).

The effect of irrigation quantity on $K W$ was significant $(P<0.05)$ in 2013 , but not significant in 2014 (Table 3). Compared with W1 in 2013, W2 increased the $K W$ by $3.5 \%$, but $\mathrm{W} 3$ reduced it by $9 \%$, respectively. Compared with W1 in 2014, W2 and W3 reduced the $K W$ by $2.1 \%$ and $3.2 \%$, respectively. The effect of $\mathrm{N}$ rate on $K W$ was not significant in either year (Table 3), indicating that increasing $\mathrm{N}$ rate did not improve the $K W$. In addition, the interaction of irrigation and $\mathrm{N}$ had no significant effect on $K N$ in either year (Table 3).

Table 3 Effects of different irrigation quantity and $\mathrm{N}$ rate on kernel numbers per plant $(K N), 100$-kernel weight $(K W)$ and harvest index $(H I)$ of maize for seed with film-mulching in 2013 and 2014

\begin{tabular}{|c|c|c|c|c|c|c|c|c|c|c|}
\hline \multirow{2}{*}{$\frac{2013}{\text { Irrigation level }}$} & \multicolumn{4}{|c|}{$\mathrm{N}$ level } & \multicolumn{3}{|c|}{2014} & \multicolumn{2}{|c|}{$\mathrm{N}$ level } & \multirow[b]{2}{*}{ Mean } \\
\hline & N500 & N400 & N300 & Mean & & Irrigation level & N500 & N300 & N100 & \\
\hline \multicolumn{11}{|l|}{$K N$ per plant } \\
\hline W1 & $156 \mathrm{a}$ & $157 \mathrm{a}$ & $144 \mathrm{a}$ & 152 & & W1 & $213 a$ & $188 \mathrm{ab}$ & $188 \mathrm{ab}$ & 197 \\
\hline W2 & $92 \mathrm{bc}$ & $111 \mathrm{ab}$ & $92 \mathrm{bc}$ & 98 & & W2 & $145 \mathrm{~cd}$ & $167 \mathrm{bc}$ & $143 \mathrm{~cd}$ & 152 \\
\hline W3 & $63 \mathrm{c}$ & $51 \mathrm{c}$ & $59 \mathrm{c}$ & 58 & & W3 & $113 \mathrm{de}$ & $96 \mathrm{ef}$ & $68 \mathrm{f}$ & 93 \\
\hline Mean & 104 & 106 & 98 & & & Mean & 157 & 150 & 133 & \\
\hline \multicolumn{11}{|l|}{$K W / \mathrm{g}$} \\
\hline W1 & $26.93 \mathrm{ab}$ & $25.69 \mathrm{ab}$ & $27.76 \mathrm{ab}$ & 26.79 & & W1 & $26.19 a$ & $26.54 \mathrm{a}$ & $26.11 \mathrm{a}$ & 26.28 \\
\hline W2 & $26.89 \mathrm{ab}$ & $28.15 \mathrm{a}$ & $28.14 \mathrm{a}$ & 27.73 & & W2 & $26.22 \mathrm{a}$ & $25.69 \mathrm{a}$ & $25.24 \mathrm{a}$ & 25.72 \\
\hline W3 & 24.49ab & $24.89 \mathrm{ab}$ & $23.78 b$ & 24.39 & & W3 & $25.44 \mathrm{a}$ & $25.60 \mathrm{a}$ & $25.28 \mathrm{a}$ & 25.44 \\
\hline Mean & 26.10 & 26.24 & 26.56 & & & Mean & 25.95 & 25.94 & 25.54 & \\
\hline \multicolumn{11}{|l|}{$H I / \%$} \\
\hline W1 & $32.4 \mathrm{a}$ & $31.5 \mathrm{a}$ & $34.3 \mathrm{a}$ & 32.7 & & W1 & $30.8 \mathrm{a}$ & $29.9 \mathrm{ab}$ & $31.0 \mathrm{a}$ & 30.6 \\
\hline W2 & $26.4 \mathrm{ab}$ & $27.5 \mathrm{ab}$ & $22.3 \mathrm{abc}$ & 25.4 & & W2 & $26.5 \mathrm{ab}$ & $30.1 \mathrm{a}$ & $24.5 \mathrm{abc}$ & 27.0 \\
\hline W3 & $16.5 \mathrm{bc}$ & $12.6 \mathrm{c}$ & $15.7 \mathrm{bc}$ & 14.9 & & W3 & $23.0 \mathrm{bc}$ & $18.9 \mathrm{~cd}$ & $14.8 \mathrm{~d}$ & 18.9 \\
\hline Mean & 25.1 & 23.9 & 24.1 & & & Mean & 26.8 & 26.3 & 23.4 & \\
\hline \multicolumn{11}{|l|}{ Significance test } \\
\hline & $\mathrm{KN}$ & & KW & & $\mathrm{HI}$ & & $\mathrm{KN}$ & & KW & HI \\
\hline Irrigation level & $* * *$ & & * & & $* * *$ & & $* * *$ & & NS & $* * *$ \\
\hline $\mathrm{N}$ level & NS & & NS & & NS & & $*$ & & NS & NS \\
\hline $\begin{array}{l}\text { Irrigation level } \\
{ }^{*} \mathrm{~N} \text { level }\end{array}$ & NS & & NS & & NS & & NS & & NS & NS \\
\hline
\end{tabular}

Note: Means within each column followed by different letters are statistically different at $P<0.05$. NS, no significance; ***, significance at $P<0.001 ; * *$, significance at $P<0.01 ; *$, significance at $P<0.05$. 
Jia et al. indicated that a low irrigation quantity (263 mm) significantly decreases $K W$ and number in maize. A low $\mathrm{N}$ rate $\left(100 \mathrm{~kg} \cdot \mathrm{hm}^{-2}\right)$ decreased kernel weight significantly, but affected $K N$ depending on irrigation quantity and cultivar ${ }^{[10]}$. Nesmith and Ritchie showed that water deficit decreased the yield because water deficit reduced the number of well-developed kernels before the blossom stage ${ }^{[7]}$. Claassen and Shaw found that water stress reduced $K N$ before silking and pollination stages, and it reduced $K W$ at or after silking and pollination stage $^{[6]}$. In this study, high irrigation quantity gave the highest $K N$, but lowering irrigation quantity decreased $K N$ markedly and $K W$ slightly. A possible reason is that severe drought affected the quantity and activity of pollen in male plants before anthesis, leading to a reduction in the number of well-developed kernels infemale plants, thus reducing $K N$. As well-developed kernels were relatively few in the reproductive growth stage, the female plants were basically able to provide enough carbohydrates to meet the needs of kernel development, even under water stress, so lowering irrigation quantity affected $K W$ only slightly. In this study, low $\mathrm{N}$ rate had satisfactory $K N$ and $K W$ of maize for seed and high $\mathrm{N}$ rate only affected theses lightly, possibly because of high $\mathrm{N}$ fertilization in the arid Hexi Corridor region of north-west China. Pandey et al. and Moser et al. showed that reducing the quantity of irrigation and $\mathrm{N}$ decreased $K N$ and $K W$ of maize significantly, and it reduces $K N$ more significantly than $K W^{[8,9]}$. Others studies have also shown that water stress reduces $K N$ of maize significantly, which is similar to our study ${ }^{[6,38]}$.

The $K N$ of W1N500 in 2013 and 2014 were 156 and 213 kernels per plant, respectively. Generally, lowering irrigation quantity strongly reduced $K N$. However, compared with W1N500, W1N300 in 2013 had a lower $K N$ but it was not a significant decrease (Table 3). Likewise, compared with W1N500, W1N100 in 2014 had a lower the $K N$, but it was not a significant decrease (Table 3 ). Thus low $\mathrm{N}$ rates $\left(100-300 \mathrm{~kg} \cdot \mathrm{hm}^{-2}\right)$ could largely maintain $K N$ of maize for seed when soil moisture content is above $65 \%-70 \% \mathrm{FC}$ in this region.

\subsection{Biomass partitioning}

$P I_{\text {stem }}$ showed a single peak, reaching the maximum (about 0.7 ) about 80 days after sowing. $P I_{\text {stem }}$ was not significantly different between different treatments at the early growth stage, but it was significantly different during later growth stage (Fig. 1a, Fig. 1d). $P I_{\text {stem }}$ in different treatments at harvest ranged from 0.321 to 0.470 and 0.325 to 0.441 in 2013 and 2014 , respectively (Table 4). The effect of irrigation quantity on $P I_{\text {stem }}$ at harvest was significant in both years (Table 4). In 2013, compared to $\mathrm{W} 1, \mathrm{~W} 2$ and $\mathrm{W} 3$ increased $P I_{\text {stem }}$ at harvest by $-9.2 \%$ and $-29.3 \%$, respectively. In 2014, compared to W1, W2 and W3 increased $P I_{\text {stem }}$ at harvest by $4.5 \%$ and $18.4 \%$, respectively. However, the effects and interaction of $\mathrm{N}$ rate were not significant in either year (Table 4).

$P I_{\text {leaf }}$ decreased with the advance of growth stage (Fig. 1b, Fig. 1e). $P I_{\text {leaf }}$ under different irrigation and $\mathrm{N}$ treatments at harvest ranged from 0.160 to 0.214 and 0.137 to 0.165 in 2013 and 2014, respectively (Table 4). The effect of irrigation quantity on $P I_{\text {leaf }}$ at harvest was significant in both years (Table 4). In 2013, compared to $\mathrm{W} 1, \mathrm{~W} 2$ and $\mathrm{W} 3$ increased $P I_{\text {leaf }}$ at harvest by $10.4 \%$ and $19.8 \%$, respectively. In 2014, compared to $\mathrm{W} 1, \mathrm{~W} 2$ and W3 increased $P I_{\text {leaf }}$ at harvest by $7.5 \%$ and $15.6 \%$, respectively. However, the effects and interaction of $\mathrm{N}$ rate were not significant in either year (Table 4).

$P I_{\text {ear }}$ increased after the flowering stage (Fig. 1c, Fig. 1f). $P I_{\text {ear }}$ under different irrigation and $\mathrm{N}$ treatments at harvest ranged from 0.326 to 0.519 and 0.394 to 0.530 in 2013 and 2014, respectively (Table 4). The effect of irrigation quantity on $P I_{\text {ear }}$ at harvest was significant in both years (Table 4). In 2013, compared to W1, W2 and W3 decreased $P I_{\text {ear }}$ at harvest by $10.1 \%$ and $27.9 \%$, respectively. In 2014, compared to $\mathrm{W} 1, \mathrm{~W} 2$ and $\mathrm{W} 3$ decreased $P I_{\text {ear }}$ at harvest by $14.7 \%$ and $26.5 \%$, respectively. However, the effects and interaction of $\mathrm{N}$ rate were not significant in either year (Table 4).

Thus $P I_{\text {stem }}$ and $P I_{\text {leaf }}$ increased significantly but $P I_{\text {ear }}$ decreased significantly with the decrease in irrigation quantity, indicating that maize for seed generally allocated more assimilates to stems and leaves and fewer assimilates to ears under drought conditions. However, $P I_{\text {stem }}, P I_{\text {leaf }}$ and $P I_{\text {ear }}$ did not significantly change with the decrease of $\mathrm{N}$ input, indicating that for a certain range of $\mathrm{N}$ rates (from 500 to $100 \mathrm{~kg} \cdot \mathrm{hm}^{-2}$ ), lowering $\mathrm{N}$ input had no effect on assimilate allocation among aboveground organs of maize for seed. According to source-sink theory, lower assimilate allocated to the ear can result from lower source strength, transport capacity or sink strength. Marcelis et al. indicated that sink strength is the important factor determining biomass partitioning in the whole plant ${ }^{[39]}$. For cereals, grain is the most important sink organ after flowering ${ }^{[0]}$. Thus lower sink strength can lead to lower assimilate allocation to ear, and reducing irrigation quantity decreased sink strength, and increasing $\mathrm{N}$ input did not increase sink strength in this study.

\subsection{Harvest index}

The effect of irrigation quantity on $H I$ was extremely significant $(P<0.01)$ in both years (Table 3$)$. In 2013, compared to $\mathrm{W} 1, \mathrm{~W} 2$ and $\mathrm{W} 3$ reduced $H I$ by $22.4 \%$ and $54.4 \%$, respectively. In 2014 , compared to $\mathrm{W} 1, \mathrm{~W} 2$ and W3 reduced $H I$ by $11.6 \%$ and $38.2 \%$, respectively. The effect of $\mathrm{N}$ rate on $H I$ was not significant in either year (Table 3). Although the effect of $\mathrm{N}$ rate on $H I$ was not significant, $H I$ was reduced more significantly when $\mathrm{N}$ rate dropped from 300 to $100 \mathrm{~kg} \cdot \mathrm{hm}^{-2}$. In addition, the interaction of irrigation quantity and $\mathrm{N}$ rate had no significant effect on $\mathrm{HI}$ in either year (Table 3). 
(a)

(b)

(c)

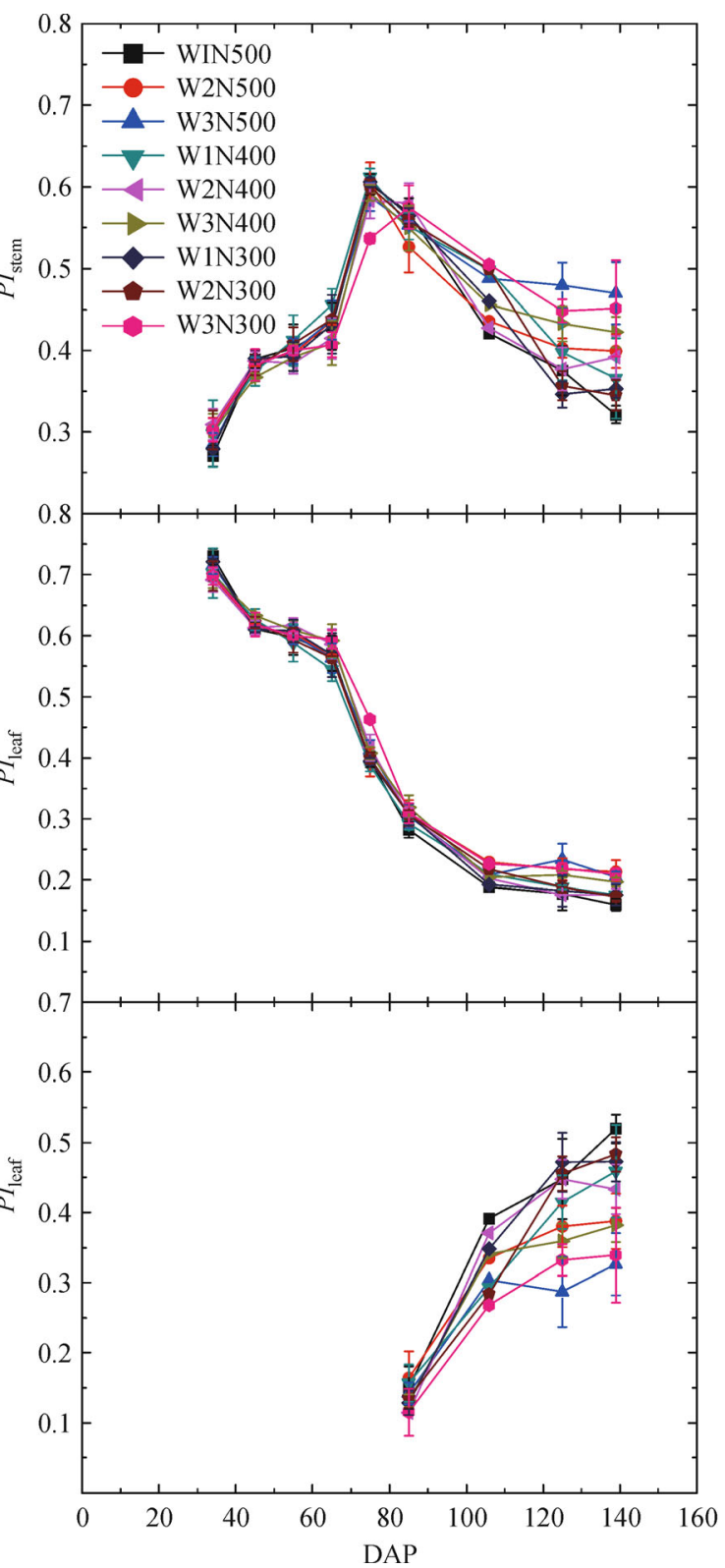

(d)

(e)

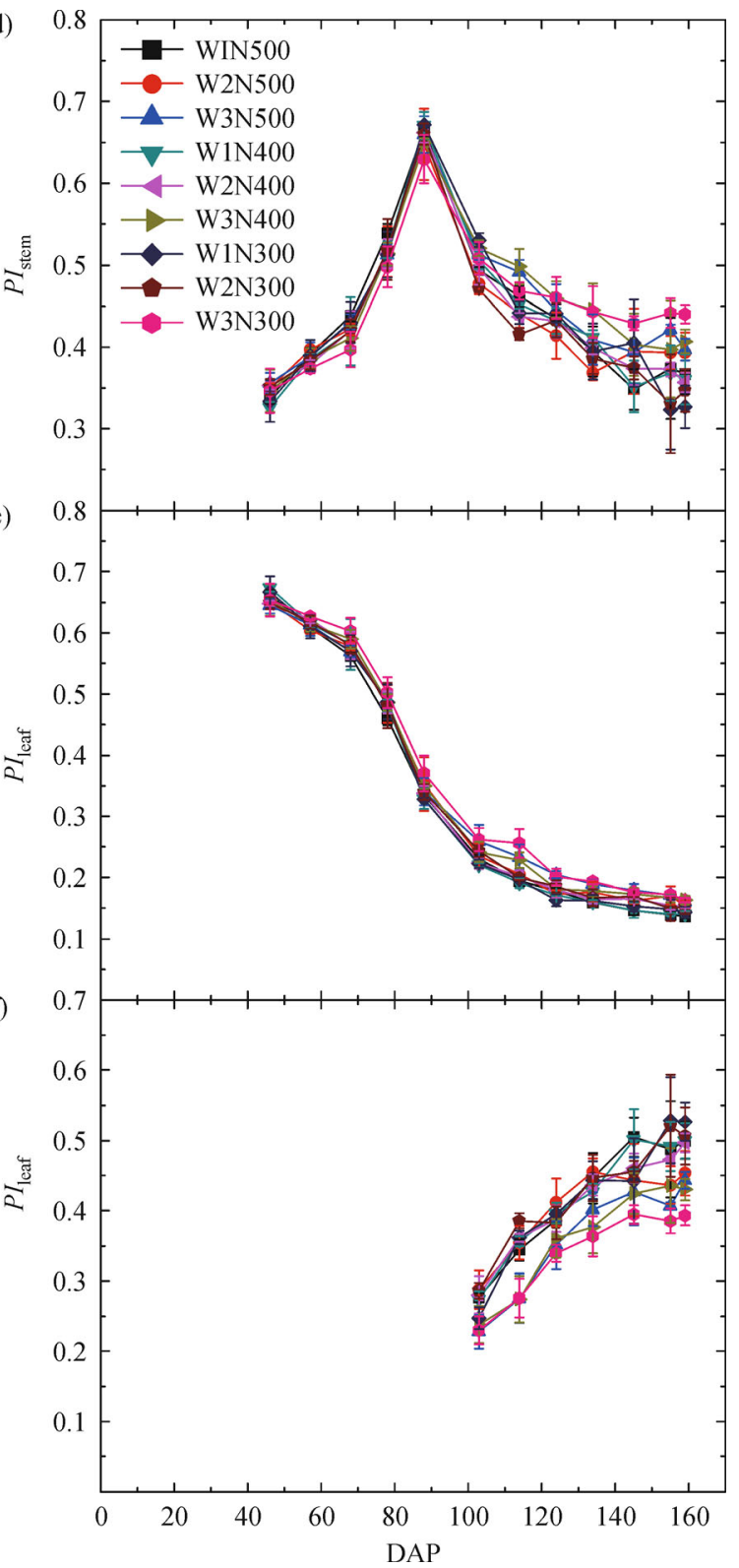

Fig. 1 Variations of stem partitioning index $\left(P I_{\text {stem }}\right)$, leaf partitioning index $\left(P I_{\text {leaf }}\right)$ and ear partitioning index $\left(P I_{\text {ear }}\right)$ of maize for seed production against days after planting (DAP) in $2013(\mathrm{a}-\mathrm{c})$ and $2014(\mathrm{~d}-\mathrm{f})$

Farré and Faci found that $H I$ of maize decreased significantly with increased of water stress, ranging from 0.51 to 0.03 , indicating that $H I$ is very sensitive to the irrigation quantity ${ }^{[28]}$. Other studies have also shown that water stress reduces $H I^{[29,30]}$, which was similar to our findings on maize for seed production. However, Kang et al. showed that water deficit at the seedling and elongation stages increased $H I$ but reduced aboveground biomass significantly with lower yield loss in the semi-arid Loess Plateau of north-west China ${ }^{[15]}$. Zhang et al. conducted a field experiment with winter wheat, involving six irrigation treatments (from 0 to 5 irrigation applications) in the North China Plain for 6 years, and found that $H I$ decreased with increased water supply, and only in very dry seasons (seasonal rainfall was less than $80 \mathrm{~mm}$ ) was the $H I$ of the rain-fed treatment reduced $^{[32]}$. It also concluded that reducing irrigation quantity increases $H I$ of winter wheat in northern China, because grains are filled more quickly than those of well-watered controls and less assimilate remained in the temporary storage organs stem and sheath ${ }^{[31]}$. These results are different from maize for seed production in this study. There are two possible reasons for this. Firstly, the previous studies were conducted in the semi arid or humid climate with mean annual rainfall of 584, 400-600 and $600 \mathrm{~mm}$, respectively ${ }^{[15,31,32]}$, so $H I$ is less dependent on irrigation. However, our study was conducted in extremely dry conditions with mean annual rainfall of $164 \mathrm{~mm}$, so $H I$ 
Table 4 Effect of irrigation quantity and $\mathrm{N}$ rate management on stem partitioning index $\left(P I_{\text {stem }}\right)$, leaf partitioning index $\left(P I_{\text {leaf }}\right)$ and ear partitioning index $\left(P I_{\text {ear }}\right)$ of maize for seed production with film-mulching at harvest in 2013 and 2014

\begin{tabular}{|c|c|c|c|c|c|c|c|c|c|}
\hline \multirow{2}{*}{$\frac{2013}{\text { Irrigation level }}$} & \multicolumn{4}{|c|}{$\mathrm{N}$ rate } & \multirow{2}{*}{$\begin{array}{l}2014 \\
\text { Irrigation level }\end{array}$} & \multicolumn{4}{|c|}{$\mathrm{N}$ rate } \\
\hline & N500 & N400 & N300 & Mean & & N500 & N300 & N100 & Mean \\
\hline \multicolumn{10}{|l|}{$P I_{\text {stem }}$} \\
\hline W1 & $0.321 \mathrm{c}$ & $0.366 b c$ & $0.352 b c$ & 0.346 & W1 & $0.364 a b$ & $0.360 \mathrm{ab}$ & $0.325 \mathrm{a}$ & 0.349 \\
\hline W2 & $0.399 \mathrm{abc}$ & $0.392 \mathrm{abc}$ & $0.344 \mathrm{c}$ & 0.378 & W2 & $0.396 b c$ & $0.354 \mathrm{ab}$ & $0.346 \mathrm{ab}$ & 0.365 \\
\hline W3 & $0.470 \mathrm{a}$ & $0.422 \mathrm{abc}$ & $0.451 \mathrm{ab}$ & 0.448 & W3 & $0.396 \mathrm{bc}$ & $0.404 b c$ & $0.441 \mathrm{bc}$ & 0.414 \\
\hline Mean & 0.397 & 0.393 & 0.382 & & Mean & 0.385 & 0.373 & 0.371 & \\
\hline \multicolumn{10}{|l|}{$P I_{\text {leaf }}$} \\
\hline W1 & $0.160 \mathrm{c}$ & $0.175 \mathrm{abc}$ & $0.175 \mathrm{abc}$ & 0.170 & W1 & $0.137 \mathrm{a}$ & $0.139 \mathrm{ab}$ & $0.145 \mathrm{abc}$ & 0.141 \\
\hline W2 & $0.214 \mathrm{a}$ & $0.176 \mathrm{abc}$ & $0.173 b c$ & 0.188 & W2 & $0.151 \mathrm{abc}$ & $0.152 \mathrm{abc}$ & $0.150 \mathrm{abc}$ & 0.151 \\
\hline W3 & $0.204 a b$ & $0.197 \mathrm{abc}$ & $0.210 \mathrm{ab}$ & 0.204 & W3 & $0.160 \mathrm{abc}$ & $0.163 b c$ & $0.165 \mathrm{c}$ & 0.162 \\
\hline Mean & 0.193 & 0.183 & 0.186 & & Mean & 0.149 & 0.151 & 0.153 & \\
\hline \multicolumn{10}{|l|}{$P I_{\text {ear }}$} \\
\hline W1 & $0.519 \mathrm{a}$ & $0.459 \mathrm{abc}$ & $0.472 \mathrm{ab}$ & 0.483 & W1 & $0.499 \mathrm{ab}$ & $0.501 \mathrm{ab}$ & $0.530 \mathrm{a}$ & 0.510 \\
\hline W2 & $0.388 \mathrm{abcd}$ & $0.433 \mathrm{abcd}$ & $0.483 \mathrm{ab}$ & 0.435 & W2 & $0.453 \mathrm{abc}$ & $0.494 \mathrm{ab}$ & $0.504 \mathrm{ab}$ & 0.484 \\
\hline W3 & $0.326 \mathrm{~d}$ & $0.381 \mathrm{bcd}$ & $0.339 \mathrm{~cd}$ & 0.349 & W3 & $0.444 \mathrm{bc}$ & $0.433 b c$ & $0.394 \mathrm{c}$ & 0.424 \\
\hline Mean & 0.411 & 0.424 & 0.431 & & Mean & 0.465 & 0.476 & 0.476 & \\
\hline \multicolumn{10}{|l|}{ Significance test } \\
\hline & & $P I_{\text {stem }}$ & $P I_{\text {leaf }}$ & $P I_{\text {ear }}$ & & $P I_{\text {stem }}$ & $P I_{\text {leaf }}$ & $P I_{\text {ear }}$ & \\
\hline \multicolumn{2}{|l|}{ Irrigation level } & $* *$ & $* *$ & $* *$ & & $* *$ & $* *$ & $* *$ & \\
\hline \multicolumn{2}{|l|}{$\mathrm{N}$ rate } & NS & NS & NS & & NS & NS & NS & \\
\hline \multicolumn{2}{|c|}{ Irrigation level $* \mathrm{~N}$ rate } & NS & NS & NS & & NS & NS & NS & \\
\hline
\end{tabular}

Note: Means within each column followed by different letters are statistically different at $P<0.05$. NS, not significant; ***, significance at $P<0.001 ; * *$, significance at $P<0.01 ; *$, significance at $P<0.05$.

might be more sensitive to irrigation. Secondly, HI of maize for seed production is controlled by both male and female plants, so water deficit may affect the quantity of pollen in the male plants and the activity of filaments in female plants, which can lead to lower HI. But the effects of different water and $\mathrm{N}$ treatments on the number of pollen grains in the male plants and the activity of filaments in female plants are unclear and need further study.

In contrast, $\mathrm{N}$ application had no effect on $\mathrm{HI}$ of tropical maize $^{[9,34]}$ and temperate maize ${ }^{[33]}$. In this study, $\mathrm{N}$ rate also had no significant effect on $H I$. This could have been related to high initial soil $\mathrm{N}$ content and high $\mathrm{N}$ rate. However, Pandey et al. found that $\mathrm{N}$ stress decreased $\mathrm{HI}$ of maize in the Sahelian climate, and Hammad et al. found similar result ${ }^{[35,41]}$. In this study, HI decreased more significantly when $\mathrm{N}$ rate was reduced from 300 to $100 \mathrm{~kg} \cdot \mathrm{hm}^{-2}$, indicating that further reducing $\mathrm{N}$ input may significantly reduce $H I$.

\subsection{Correlation of growth measures and evapotranspiration}

$K N$ had a clear linear relationship with $E T$ (Fig. 2a), which was similar to the result of Otegui et al. ${ }^{[42]}$. However, no significant correlation was found between $K W$ and $E T$ (data not shown), since $K W$ did not change under the different irrigation and $\mathrm{N}$ treatments.

$H I$ had a weak linear relationship with $E T$ under different water and $\mathrm{N}$ treatments (Fig. 2b), indicating that $H I$ could be related to not only total $E T$ over the whole growth period, but also $E T$ at different growth stages. Kang et al. found a quadratic relationship between $H I$ and $E T$ in winter wheat $\left(H I=-5 \times 10^{-6} E T^{2}+0.0034 E T-0.2352\right.$, $R^{2}=0.4763$ ), which contrasts with our result ${ }^{[43]}$. This may be related to the different climatic conditions and crop species in their study.

$P I_{\text {stem }}, P I_{\text {leaf }}$ and $P I_{\text {ear }}$ at harvest showed a linear relationship with $E T$ (Fig. 2c, Fig. 2d, Fig.2e), which can provide basis for modeling the partitioning of biomass among different aboveground organs.

\section{Conclusions}

Lowering irrigation quantity significantly reduced $K N$, and reducing nitrogen fertilizer rate also decreased $K N$. However, $K W$ was relatively stable under different 


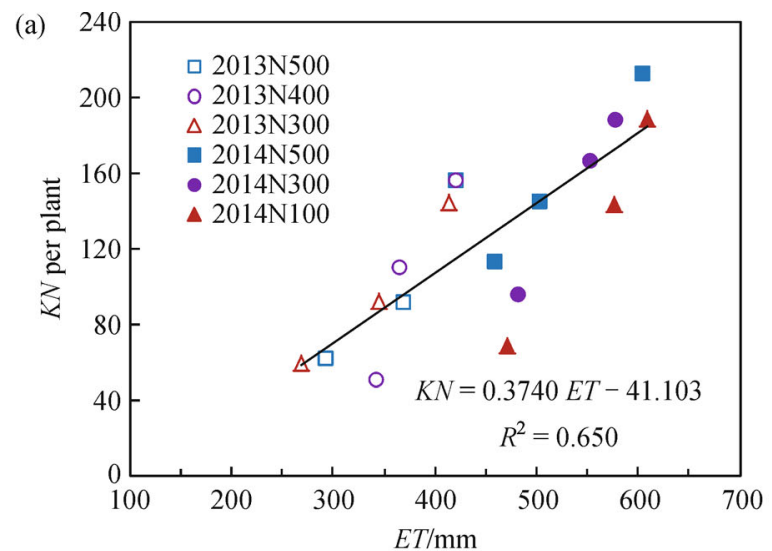

(b)
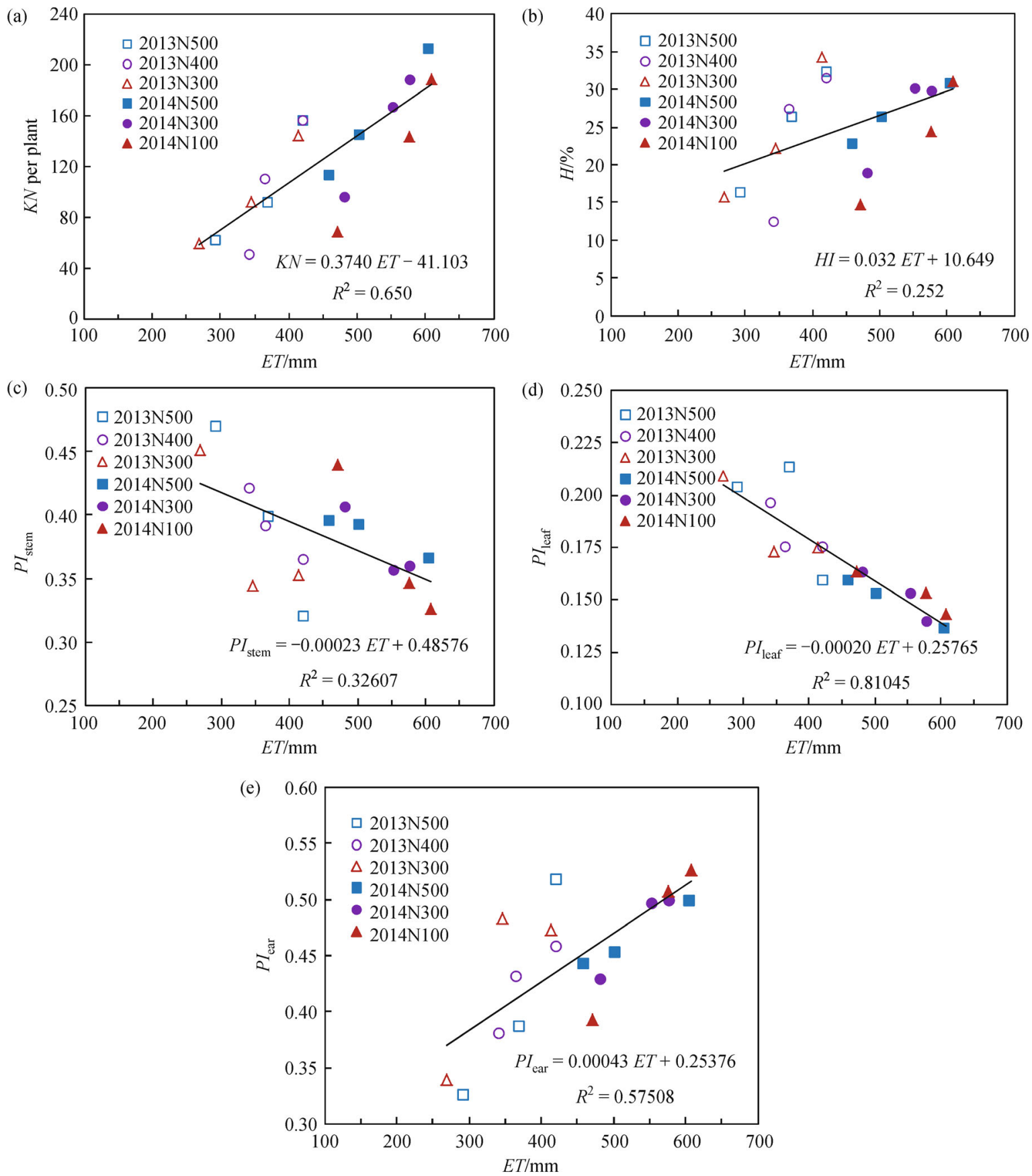

Fig. 2 Regression equations for kernel numbers per plant ( $K N$ per plant), biomass partitioning index $(P I)$ at harvest and harvest index $(H I, \%)$ of maize for seed with film-mulching response to evapotranspiration $(E T, \mathrm{~mm})$ in 2013 and 2014 under different nitrogen rates

irrigation and $\mathrm{N}$ treatments. Lowering irrigation quantity significantly increased $P I_{\text {stem }}$ and $P I_{\text {leaf }}$, and decreased $P I_{\text {ear }}$ at harvest, but lowering $\mathrm{N}$ input (from 500 to $100 \mathrm{~kg} \mathrm{~N} \cdot \mathrm{hm}^{-2}$ ) did not significantly reduce $P I_{\text {stem }}, P I_{\text {leaf }}$, and $P I_{\text {ear }}$ at harvest. $H I$ was significantly reduced by lowering irrigation quantity, while it was not significantly reduced by lowering $\mathrm{N}$ input. Linear relationships were found between $K N, H I, P I_{\text {stem }}, P I_{\text {leaf }}$, and $P I_{\text {ear }}$ at harvest and $E T$.
Acknowledgements This research was supported by the National Natural Science Foundation of China (91425302, 51321001, 51379208), and the Discipline Innovative Engineering Plan (B14002).

Compliance with ethics guidelines Hui Ran, Shaozhong Kang, Fusheng Li, Ling Tong, and Taisheng Du declare that they have no conflict of interest or financial conflicts to disclose.

This article does not contain any studies with human or animal subjects performed by any of the authors. 


\section{References}

1. Zand-Parsa S, Sepaskhah A. Optimal applied water and nitrogen for corn. Agricultural Water Management, 2001, 52(1): 73-85

2. Gheysari M, Mirlatifi S, Bannayan M, Homaee M, Hoogenboom G. Interaction of water and nitrogen on maize grown for silage. Agricultural Water Management, 2009, 96(5): 809-821

3. Du T, Kang S, Sun J, Zhang X, Zhang J. An improved water use efficiency of cereals under temporal and spatial deficit irrigation in north China. Agricultural Water Management, 2010, 97(1): 66-74

4. Islam M, Garcia S, Horadagoda A. Effects of irrigation and rates and timing of nitrogen fertilizer on dry matter yield, proportions of plant fractions of maize and nutritive value and in vitro gas production characteristics of whole crop maize silage. Animal Feed Science and Technology, 2012 , 172(3-4): 125-135

5. Du T, Kang S, Zhang J, Davies W. Deficit irrigation and sustainable water-resource strategies in agriculture for China's food security. Journal of Experimental Botany, 2015, 66(8): 2253-2269

6. Claassen M, Shaw R. Water deficit effects on corn. I. Grain components. Agronomy Journal, 1970, 62(5): 652-655

7. NeSmith D, Ritchie J. Short-term and long-term responses of corn to a preanthesis soil-water deficit. Agronomy Journal, 1992, 84(1): 107-113

8. Pandey R, Maranville J, Admou A. Deficit irrigation and nitrogen effects on maize in a Sahelian environment: I. Grain yield and yield components. Agricultural Water Management, 2000, 46(1): 1-13

9. Moser S, Feil B, Jampatong S, Stamp P. Effects of pre-anthesis drought, nitrogen fertilizer rate, and variety on grain yield, yield components, and harvest index of tropical maize. Agricultural Water Management, 2006, 81(1-2): 41-58

10. Jia X, Shao L, Liu P, Zhao B, Gu L, Dong S, Bing S, Zhang J, Zhao B. Effect of different nitrogen and irrigation treatments on yield and nitrate leaching of summer maize (Zea mays L.) under lysimeter conditions. Agricultural Water Management, 2014, 137(1385): 92103

11. Thornley J. A balanced quantitative model for root: shoot ratios in vegetative plants. Annals of Botany, 1972, 68(145): 211-264

12. Olff H, Andel J V, Bakker J P. Biomass and shoot/root allocation of five species from a grassland succession series at different combinations of light and nutrient supply. Functional Ecology, 1990, 4(2): 193-200

13. Poorter H, Nagel O. The role of biomass allocation in the growth response of plants to different levels of light, $\mathrm{CO}_{2}$, nutrients and water: a quantitative review. Australian Journal of Plant Physiology, 2000, 27(6): 595-607

14. Poorter H, Remkes C, Lambers H. Carbon and nitrogen economy of 24 wild species differing in relative growth rate. Plant Physiology, 1990, 94(2): 621-627

15. Kang S, Shi W, Zhang J. An improved water-use efficiency for maize grown under regulated deficit irrigation. Field Crops Research, 2000, 67(3): 207-214

16. Sharp R, Davies W. Regulation of growth and development of plants growing with a restricted supply of water. In: Jones $\mathrm{H}$, Flowers T, Jones M, eds. Plants under Stress. Cambridge: Cambridge University Press, 1989, 71-93
17. Steinberg S, Miller J, McFarland M. Dry matter partitioning and vegetative growth of young peach trees under water stress. Functional Plant Biology, 1990, 17(1): 23-36

18. Frensch J. Primary responses of root and leaf elongation to water deficits in the atmosphere and soil solution. Journal of Experimental Botany, 1997, 48(5): 985-999

19. Xiloyannis C, Dichio B, Nuzzo V, Celano G. Defence strategies of olive against water stress, III International Symposium on Olive Growing 474. Acta Hortic, 1997, 423-426

20. Munns R. Comparative physiology of salt and water stress. Plant, Cell \& Environment, 2002, 25(2): 239-250

21. Yin C, Wang X, Duan B, Luo J, Li C. Early growth, dry matter allocation and water use efficiency of two sympatric Populus species as affected by water stress. Environmental and Experimental Botany, 2005, 53(3): 315-322

22. Martin P, Stephens W. Willow growth in response to nutrients and moisture on a clay landfill cap soil. I. Growth and biomass production. Bioresource Technology, 2006, 97(3): 437-448

23. Villagra $P$, Cavagnaro J. Water stress effects on the seedling growth of Prosopis argentina and Prosopis alpataco. Journal of Arid Environments, 2006, 64(3): 390-400

24. Wu F, Bao W, Li F, Wu N. Effects of drought stress and N supply on the growth, biomass partitioning and water-use efficiency of Sophora davidii seedlings. Environmental and Experimental Botany, 2008, 63(1-3): 248-255

25. Di Vaio C, Marallo N, Marino G, Caruso T. Effect of water stress on dry matter accumulation and partitioning in pot-grown olive trees (cv Leccino and Racioppella). Scientia Horticulturae, 2013, 164: 155-159

26. González J, Gallardo M, Hilal M, Rosa M, Prado F. Physiological responses of quinoa (Chenopodium quinoa Willd.) to drought and waterlogging stresses: dry matter partitioning. Botanical Studies, 2009, 50(1): 35-42

27. DeLougherty R, Crookston R. Harvest index of corn affected by population density, maturity rating, and environment. Agronomy Journal, 1979, 71(4): 577-580

28. Farré I, Faci J. Comparative response of maize (Zea mays L.) and sorghum (Sorghum bicolor L. Moench) to deficit irrigation in a Mediterranean environment. Agricultural Water Management, 2006, 83(1-2): 135-143

29. Muchow R. Comparative productivity of maize, sorghum and pearl millet in a semi-arid tropical environment II. Effect of water deficits. Field Crops Research, 1989, 20(3): 207-219

30. Bolaños J, Edmeades G. Eight cycles of selection for drought tolerance in lowland tropical maize. I. Responses in grain yield, biomass, and radiation utilization. Field Crops Research, 1993, 31 (s3-4): 233-252

31. Zhang J, Sui X, Li B, Su B, Li J, Zhou D. An improved water-use efficiency for winter wheat grown under reduced irrigation. Field Crops Research, 1998, 59(2): 91-98

32. Zhang X, Chen S, Sun H, Pei D, Wang Y. Dry matter, harvest index, grain yield and water use efficiency as affected by water supply in winter wheat. Irrigation Science, 2008, 27(1): 1-10

33. Lorens G, Bennett J, Loggale L. Differences in drought resistance between two corn hybrids. II. Component analysis and growth rates. Agronomy Journal, 1987, 79(5): 808-813 
34. Siri B. Influence of drought stress on seedling growth and leaf anatomy as related to yield components and grain yield of tropical maize cultivars. Dissertation for the Doctoral Degree. Kiel: Christians Albrechts University, 1993

35. Pandey R, Maranville J, Chetima M. Deficit irrigation and nitrogen effects on maize in a Sahelian environment: II. Shoot growth, nitrogen uptake and water extraction. Agricultural Water Management, 2000, 46(1): 15-27

36. Li S, Kang S, Zhang L, Du T, Tong L, Ding R, Guo W, Zhao P, Chen X, Xiao H. Ecosystem water use efficiency for a sparse vineyard in arid northwest China. Agricultural Water Management, 2015, 148(148): 24-33

37. Allen R, Pereira L, Raes D, Smith M. Crop EvapotranspirationGuidelines for Computing Crop Water Requirements-FAO Irrigation and Drainage paper 56. Rome: FAO, 1998

38. Fischer K, Palmer F. Tropical maize. In: Goldsworthy P R, Fisher N $\mathrm{M}$, eds. The physiology of tropical field crops. New York: Wiley,
1984, 213-248

39. Marcelis L. Sink strength as a determinant of dry matter partitioning in the whole plant. Journal of Experimental Botany, 1996, 47(301): $1281-1291$

40. Kumar R, Sarawgi A, Ramos C, Amarante S, Ismail A, Wade L. Partitioning of dry matter during drought stress in rainfed lowland rice. Field Crops Research, 2006, 98(1): 1-11

41. Hammad H, Ahmad A, Abbas F, Farhad W. Optimizing water and nitrogen use for maize production under semiarid conditions. Turkish Journal of Agriculture and Forestry, 2012, 36(5): 519-532

42. Otegui M, Andrade F, Suero E. Growth, water use, and kernel abortion of maize subjected to drought at silking. Field Crops Research, 1995, 40(2): 87-94

43. Kang S, Zhang L, Liang Y, Hu X, Cai H, Gu B. Effects of limited irrigation on yield and water use efficiency of winter wheat in the Loess Plateau of China. Agricultural Water Management, 2002, 55 (3): 203-216 